\title{
"Daughter and son: a completely different story"? Gender as a moderator of the relationship between sexism and parental attitudes
}

\begin{abstract}
BACKGROUND
During childhood, parents are the first and most important individuals who form the base of the content of gender stereotypes in children. A parent's expectations about the extent a child's behaviour should be line with gender stereotypes also depends on the intensity of a parent's sexism. A parent's sexism may be exhibited in parental attitudes. Hence, in our study we analysed the relationship between parental ambivalent sexism and parental attitudes within dyads of mothers and fathers with a special focus on the role of the gender of both parents and children.
\end{abstract}

\section{PARTICIPANTS AND PROCEDURE}

Two hundred and ninety-four couples of parents of fiveyear-olds (153 girls, 141 boys) participated. The Ambivalent Sexism Inventory (ASI) was used to measure levels of sexism, and the Parental Attitudes Scale (SPR) was used to assess parental attitudes.

\section{RESULTS}

In terms of the profile of parental attitudes, regardless of the child's sex, mothers and fathers scored highest for inconsequent and demanding attitudes, and lowest for overprotective and autonomy attitudes. The child's sex is also not important for the overall levels of parents' sexism

\begin{abstract}
- fathers exhibit higher levels of hostile sexism in comparison to mothers. Only the mothers' education level is important for levels of sexism - women with higher education exhibited the lowest levels of hostile sexism. The child's sex moderates relationships between parents' sexism and parental attitudes. In the case of mothers of sons, the intensity of benevolent sexism is negatively related to overprotective and demanding attitudes. The more educated the mothers of sons, the more demanding they were. For fathers of sons, the inconsequence attitude increases under the influence of both hostile and benevolent sexism. Among fathers of daughters, hostile sexism strengthens the overprotective attitude, while levels of both benevolent and hostile sexism as well as education influence the autonomy attitude.
\end{abstract}

\section{CONCLUSIONS}

The gender of both the parents and the child moderates the relationship between sexism and parental attitudes. The role of sexism in shaping the attitude of mothers towards sons is the most prominent - it seems that it guards the 'manliness' of young boys.

KEY WORDS

sexism; gender stereotypes; parental attitudes

ORganization - 1: Institute of Psychology, University of Gdansk, Gdansk, Poland · 2: Department of Health Psychology,

Gdansk University of Physical Education and Sport, Gdansk, Poland

AUthors' Contributions - A: Study design - B: Data collection - C: Statistical analysis · D: Data interpretation .

E: Manuscript preparation · F: Literature search · G: Funds collection

CORReSPonding AUthor - Prof. Małgorzata Lipowska, Institute of Psychology, University of Gdansk, 4 Bażyńskiego Str., 80-309 Gdansk, Poland, e-mail: malgorzata.lipowska@ug.edu.pl 


\section{BACKGROUND}

\section{GENDER STEREOTYPES AND GENDER ROLES IN A DEVELOPMENTAL PERSPECTIVE}

From a developmental perspective, gender is one of the central elements of one's identity. Gender identity is connected with an individual's sense of femininity and masculinity, and defines the degree to which "I" overlaps with the stereotypical attributes of an individual's sex (Boski, 1999; Mandal, 2004). "I am a woman" or "I am a man" implies certain notions of femininity and masculinity, as well as different elements of gender stereotypes (e.g. gender roles and personality characteristics typical for men and women) (Deaux \& Lewis, 1984). Female gender roles are connected with focusing on interpersonal bonds, providing emotional support, taking care of children, and managing the house, whereas male gender roles are centred around financial decision making and being breadwinners (Liberska \& Matuszewska, 2006; Moss-Racusin \& Rudman, 2010; Rudman, Moss-Racusin, Phelan, \& Nauts, 2012; Wood \& Eagly, 2012). A lot of research suggests that gender stereotypes are deeply rooted and resistant to change (Biernat, 1991; Diekman, Goodfriend, \& Goodwin, 2004), which, for example, is associated with the fact that the process of acquiring gender stereotypes starts at an early stage of development and takes place almost simultaneously with the process of acquiring knowledge about biological sex - recognising it and later associating it with appearance, behaviours and features (Biernat, 1991; Kosakowska, 2004). Already in the pre-school period, the discovery of one's biological sex and its permanence happens concurrently with acquiring knowledge about the differences in women's and men's behaviours that are typical for a given culture (Williams \& Best, 1990; Szmigielska \& Tomaszek, 2009).

The number of social roles an individual plays increases with age, beginning with those associated with social relations (friends, acquaintances, partners), through those associated with career (employer, employee), ending with family (spouse/ partner, adult child, parent). The way each of these roles is played depends on very many factors, among which biological sex and the attitude towards gender roles are key (Bosak, Sczesny, \& Eagly, 2012; Eagly \& Wood, 2012). Undertaking parental roles deserves special attention, since they are determined mainly by biological sex. Obviously, apart from biological sex, which determines the role of the father or the mother, it is impossible to ignore gender stereotypes, which indicate the norms for fulfilment of maternal and paternal roles (Kaźmierczak, 2015). The Biosocial Model of Origins of Sex Differences formulated by Wood and Eagly (2002) indicates how the biological differences between men and women associated with reproductive functions and differences in terms of physical strength and body size predispose the members of both sexes to undertaking specific social roles, such as those associated with parenthood or appearance. Following gender prescriptions and proscriptions may have an effect on an individual's quality of life and psychological well-being, which makes this line of research pertaining to gender stereotypes and an individual's health appear to be an important health-related issue.

According to Deaux and Lewis (1983, 1984), gender stereotypes are composed of four components: 1) personality traits, 2) social roles, 3) appearance and 4) occupations. In our article we will focus on the social roles of father and mother that enact gender stereotypes.

\section{BACKLASH EFFECTS, SEXISM AND SOCIAL ROLES}

One of the manifestations of the ubiquity of gender stereotypes is backlash effects (Rudman \& Fairchild, 2004) that relate to the perception of gender incongruent behaviour. As women and men are expected to act and behave along gender lines, behaviours that are not in line with the accepted norms for a given gender are very often subject to social scrutiny. Backlash effects and sexism ('attitudes that reinforce gender hierarchy') (Glick \& Rudman, 2010) concern both women and men (cf. Karasiewicz \& Kosakowska, 2008; Kosakowska-Berezecka, 2012; Rudman et al., 2012; Croft, Schmader, \& Block, 2015; KosakowskaBerezecka, Korzeniewska, \& Kaczorowska, 2016). Throughout history women have been both praised and punished for not being feminine enough (Eagly \& Mladinic, 1989; Glick, Wilkerson, \& Cuffe, 2015), and the same applies to men (Rudman \& Mescher, 2013; Vandello \& Bosson, 2013). Gendered behaviour is hence analysed through the lenses of gender proscriptions, as in Glick's and Fiske's Ambivalent Sexism Theory (1996), according to which two kinds of sexism depict traditional antipathy towards women (hostile sexism) alongside affection and positive feelings towards them (benevolent sexism). Hostile sexism (HS) corresponds to classic acts of prejudice, whereas benevolent sexism (BS) is based on protectionist beliefs and the overvaluing of stereotypically feminine traits, due to which women who are delicate and beautiful are more admired and desired by men. Since both forms of sexism have common ground, they are moderately positively correlated (Glick \& Fiske, 1996); this is also observed in Polish studies (Pietrzak \& Mikołajczak, 2015). Both hostile and benevolent sexism are linked with social conservatism and are an expression of preference of conservative values and views on the nature of women and men in society (Pietrzak \& Mikołajczak, 2015).
Gender as a moderator of the relationship between sexism and parental attitudes 
The Polish stereotype of femininity assumes that the fundamental roles of a woman are that of the mother, the responsibility for aesthetics (including their own physical appearance and the appearance of their home and family members), and a belief in women's resourcefulness (Liberska \& Matuszewska, 2014; Mikołajczak \& Pietrzak, 2015). Resourcefulness refers to the expectation of a well-functioning household even in situations of limited access to resources (e.g. in the era of communist rule). Its inherent aspect is a capacity for multi-tasking, valued alongside sacrifice, care, altruism and understanding - perceived as uniquely maternal and therefore female traits (Mikołajczak \& Pietrzak, 2015). The Polish stereotype of manliness, meanwhile, includes such features and competences as ease of making decisions, self-confidence, independence, an analytic mind, the ability to work efficiently under stressful conditions, dominance and competitiveness (Kosakowska-Berezecka, 2012).

However, it is important to note that nowadays the scope of features ascribed to women and men is undergoing certain changes, especially with regards to what is expected of women. Changes in defining the appropriate family and career roles for a given sex are particularly apparent (Chrzan-Dętkoś, Kosakowska-Berezecka, \& Pawlicka, 2011). This is why the extent to which behaviours of women and men are saturated with gender stereotypes may differ greatly depending on the cohort. Polish research conducted by Pietrzak and Mikołajczak (2015) confirmed higher levels of sexism among men and older individuals, as well as differences depending on levels of education (individuals with elementary education exhibited higher levels of both benevolent and hostile sexism in comparison to individuals with higher education). This variability is of huge importance for the functioning of all social groups, beginning with the family.

\section{GENDER STEREOTYPING AND PARENTAL ATTITUDES}

During childhood, parents or caregivers are the first and the most important people who provide a base for the creation of gender stereotypes among children. Parental behaviours, attitudes, or ways of emotional response are to a large extent acquired by their children. Moreover, our mothers and fathers are the first models of behavioural patterns that are consistent or inconsistent with social and gender roles and prototypes of parental care (Bochniarz, 2010; Endendijk et al., 2013). This is why both indirect and direct ways that parents influence their child are often believed to be among the determinants of how a child's attitude towards gender and sexuality will be shaped (Antill, Cunningham, \& Cotton, 2003). Parental attitudes are believed to be among the main direct ways that parents influence a child (Lauk- kanen, Ojansuu, Tolvanen, Alatupa, \& Aunola, 2014), and they are expressed in the way the parents approach their child, tactics of influencing and attitudes towards the role of being a parent itself (Ziemska, 2009). Gender, of both the adult and the child, is an important factor for the exhibited parental attitudes. Three components are usually highlighted when analysing parental attitudes: cognitive, emotionalmotivational, and behavioural components (Plopa, 2007). The cognitive component is saturated with the parent's opinions, their beliefs regarding both themselves and the child - with regard to gender roles it is directly related to the attitude of the parent towards gender stereotypes (Cunningham, 2001). Also the emotional-motivational aspect expressed in what the parent says, their emotional expression as well as the tone and the timbre of voice is very different depending on the child's sex (Aznar \& Tenenbaum, 2015). The way that grown-ups act towards their offspring - i.e. the behavioural component of the attitude - is particularly variable depending on gender (Cabrera, Fagan, Wight, \& Schadler, 2011). Gender is a factor on which it frequently depends whether or not grown-ups accept a given behaviour from a child. This refers both to the child's gender (e.g. both mothers and fathers are more likely to allow an adolescent son rather than a daughter to come back home late) and the parent's gender (e.g. mothers have often higher expectations from their daughters than sons) (De Groof, 2008; Mulvey \& Killen, 2015). Therefore parental attitudes are usually analysed separately for mothers and fathers.

Parental attitudes have an influence in many spheres. Constructs such as style of upbringing and which correction methods will be used by the parents and whether they will be successful are under the influence of parental attitudes (see Spera, 2005; Marchwicki, 2004; Möller, Nikolić, Majdandžić, \& Bögels, 2016).

\section{CHILD'S AGE, PARENTAL EDUCATION AND PARENTAL ATTITUDES}

Apart from the gender of the parents and the child, the age of the children is a very important element modifying the way parental attitudes are expressed (Liberska \& Matuszewska, 2014). The same parental attitude may be expressed differently with regards to a toddler, a pre-schooler or an adolescent (Reby, Levréro, Gustafsson, \& Mathevon, 2016; Aunola \& Nurmi, 2005; Borchet, Lewandowska-Walter, \& Rostowska, 2016).

The education level of the parent is also an important factor which significantly influences parental attitudes. Individuals with higher education tend to more frequently have attitudes which foster the positive development of children (Plopa, 2008). 
Parental attitudes are often described as positive or negative (Plopa, 2007). The majority of parental attitude models stress their multidimensionality, which means that the frequency/intensity of behaviours associated with a given attitude determine its developmental, supportive, or detrimental character (Plopa, 2008; Ziemska, 2009). Whereas positive attitudes, such as acceptance or autonomy, are associated with the optimal development of children (Spera, 2005; Raboteg-Saric \& Sakic, 2014), negative attitudes are often said to be risk factors for the occurrence of psychiatric disorders among children and youths (Young, Lennie, \& Minnis, 2011; Witkowska, 2013; Liberska \& Matuszewska, 2014; Tani, Ponti, \& Smorti, 2014). Also in this context gender is said to be an important differentiating factor. Many clinical and epidemiological studies have been devoted to the problem of frequency of occurrence of developmental and psychiatric disorders and have taken into account the criterion of sex (see Maschi, Morgen, Bradley, \& Hatcher, 2008; Eaton et al., 2012; Runions, 2014; Paulus, Backes, Sander, Weber, \& Gontard, 2015; Brown, Fite, \& Poquiz, 2016).

Both the aforementioned studies from the fields of family and educational psychology, as well as clinical psychology and psychopathology, suggest that the level of internalisation of gender stereotypes by parents influences their parenting/parental attitudes. Parental attitudes, as a tool for influencing the child's development, are an expression of the parent's values, beliefs and attitudes. The intensity of sexism of a parent is associated with the levels of their expectation of the extent to which the child will develop in accordance with gender stereotypes. Therefore we assume that parental attitudes towards their own child are an influence of sexism. No other studies, to our knowledge, have tested this assumption using samples comprising both parents.

Hence, in our study we analysed the relationship between parental ambivalent sexism and parental attitudes within dyads of mothers and fathers with a special focus on the role of the gender of both parents and children. First, we formed explorative questions:

1. What parental attitudes profile is presented by Polish mothers and fathers towards their five-year-old daughters and sons?

2. What are the levels of sexism of the studied parents?

3. Does a parent's age, their education level, area of residence and having one or more children differentiate parental attitudes and the intensity of sexism? Moreover, we formed the following hypotheses:

1. The intensity of hostile and benevolent sexism of parents influences the profile of exhibited parental attitudes towards their children.

2. Sex, both that of the parents and of the children, as well as the age and education levels of parents, moderates the association between sexism and parental attitudes.

\section{PARTICIPANTS AND PROCEDURE}

\section{PARTICIPANTS}

Two hundred and ninety-four dyads of parents of five-year-old children (153 girls and 141 boys) took part in the study $(M=5.80, S D=0.23)$. The age of children was purposely identical so as to exclude the influence of this factor on the attitudes and be able to fully focus on the moderating role of gender. Variables such as the age of parents $\left(M_{\text {mother }}=33.62, S D_{\text {mother }}=5.22\right.$, $\left.M_{\text {father }}=35.84, S D_{\text {father }}=5.52\right)$ and their education levels (14.23\% had vocational education, $37.59 \%$ secondary education, and $47.81 \%$ higher education, fathers: $32.12 \%, 36.86 \%$ and $31.02 \%$ respectively) were controlled for. The area of residence of the participants (28.10\% lived in villages, $16.42 \%$ in small towns, that is up to 20000 inhabitants, $28.83 \%$ in towns with $20000-100000$ inhabitants, and $26.25 \%$ in cities with over 100000 inhabitants), as well as whether the child had siblings ( $35.77 \%$ were only children), was also taken into account.

\section{PROCEDURE}

The Ambivalent Sexism Inventory was used to assess levels of sexism, and the Parental Attitudes Scale was used to assess parental attitudes.

Ambivalent Sexism Inventory (ASI; Glick \& Fiske, 1996, Polish adaptation by Mikołajczak \& Pietrzak, 2014). This scale has 22 items scored on a scale from 0 (completely disagree) to 5 (completely agree), clustered into two subscales: hostile sexism (HS) with 11 items (e.g., 'Most women interpret innocent remarks or acts as being sexist'; 'Women exaggerate problems at work'; 'Once a man commits, she puts him on a tight leash') and benevolent sexism (BS) with 11 items divided into three categories: Protective Paternalism ('Women should be cherished and protected by men'); Heterosexual Intimacy ('Despite accomplishment, men are incomplete without women') and Complementary Gender Differentiation ('Women have a superior moral sensibility'). The Cronbach's $\alpha$ reliability coefficients for our sample were .76 for mothers and .80 for fathers.

Parental Attitudes Scale (SPR; Plopa, 2008). The questionnaire contains 50 diagnostic statements, grouped in five dimensions corresponding to five different parental attitudes: acceptance-rejection, autonomy, overprotective, demanding, and inconsequent. The acceptance-rejection dimension describes the level of parental acceptance of the child, where low scores point to distant, insensitive and rejecting (psychologically and physically) attitudes toward the child and high scores point to accepting, supporting and sensitive parental attitudes. The autonomy dimension measures levels of parental respect for the
Gender as a moderator of the relationship between sexism and parental attitudes 
Małgorzata

Lipowska, Mariusz Lipowski, Paulina Pawlicka child's needs and ability to adjust parental behaviour to the child's developmental needs (the higher the score, the higher is the acceptance of the child's autonomy). The overprotective dimension measures the tendency to consider one's child as vulnerable, helpless and dependent. The higher the score on this dimension, the higher is the intensity of an attitude that is distrustful and overly preoccupied with the child's future. The demanding dimension focuses on parental expectations towards the child. High scores in this dimension are associated with more rigid and critical attitudes towards the child as well as with valuing submissive behaviour in the child. The inconsequent dimension measures parental inclination to inconsistent reactions dependent on their mood and daily situation as well as general parental emotional stability (Plopa, 2008).

The respondents were asked to rate on a fiveitem scale how strongly they agree or disagree with statements corresponding to five dimensions of parental attitudes. The questionnaire is available in two versions for examination of maternal and paternal attitudes. The Cronbach's $\alpha$ reliability coefficients for our sample were .85 for mothers and .86 for fathers.

\section{RESULTS}

\section{PARENTAL ATTITUDES}

The profile of parental attitudes was analysed first. Mothers and fathers scored the highest for 'inconsequent' and 'demanding' attitudes. The lowest scores were observed for 'overprotective' and 'autonomy' attitudes (Figure 1).

Mothers exhibit higher levels of the acceptance-rejection, demanding and autonomy attitudes than do fathers (Table 1). The gender of the child is of no importance for the intensity of parental attitudes; nor are the age of parents, area of residence or having one or more children.

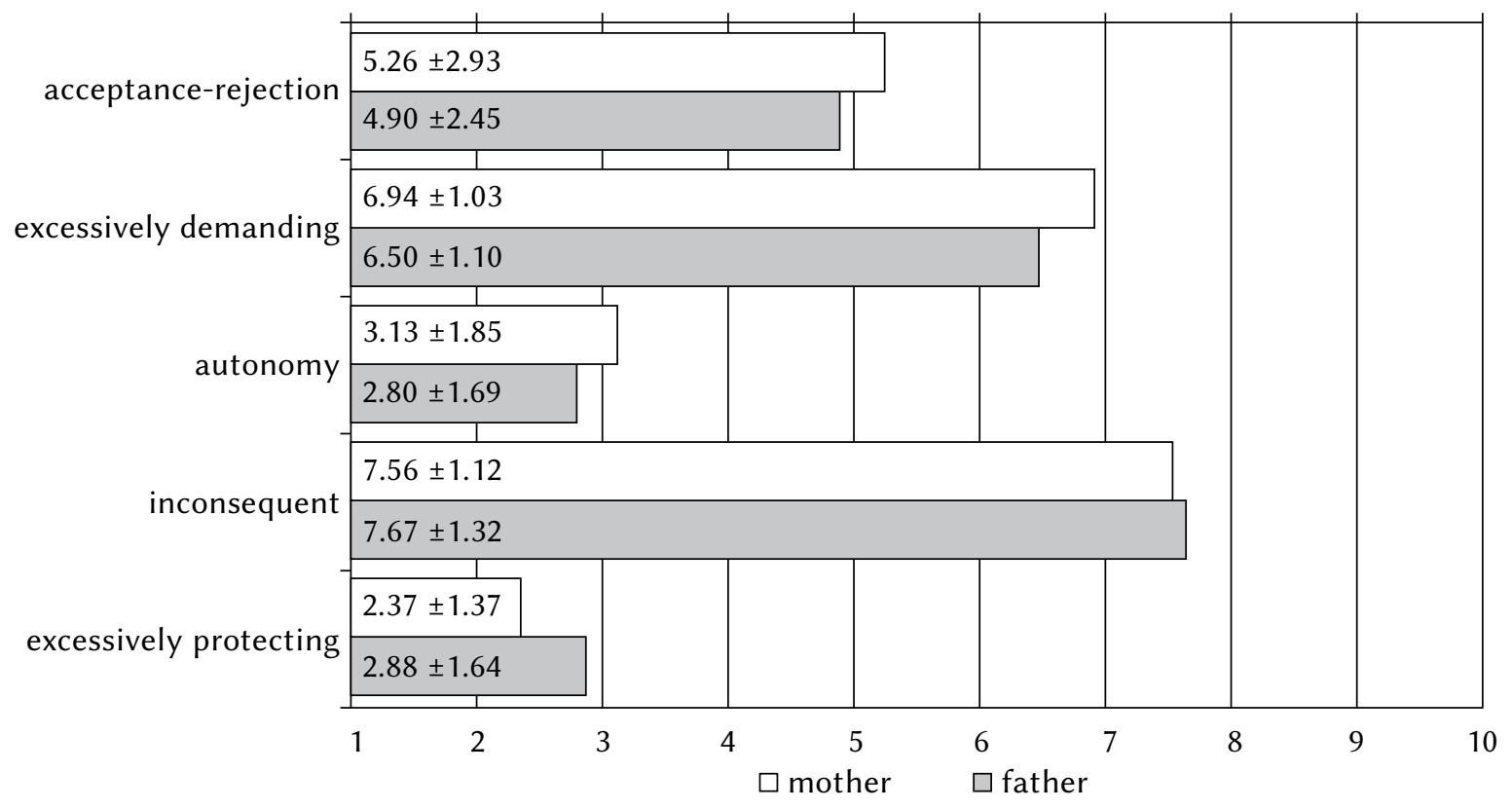

Figure 1. Intensity (in sten scores) of parental attitudes of the studied mothers and fathers.

Table 1

Differences in intensities of parental attitudes between mothers and fathers

\begin{tabular}{|c|c|c|c|c|c|c|}
\hline \multirow{2}{*}{ Parental attitude } & \multicolumn{2}{|c|}{ Mother } & \multicolumn{2}{|c|}{ Father } & \multicolumn{2}{|c|}{ Difference } \\
\hline & $M$ & $S D$ & $M$ & $S D$ & $t$ & $p$ \\
\hline Acceptance-rejection & 43.90 & 5.10 & 41.46 & 6.10 & 6.39 & $<.001$ \\
\hline Demanding & 36.56 & 4.54 & 35.64 & 4.75 & 2.99 & .003 \\
\hline Autonomy & 31.17 & 7.48 & 28.90 & 7.43 & 4.95 & $<.001$ \\
\hline Inconsequent & 31.40 & 6.16 & 31.90 & 6.75 & 1.14 & .257 \\
\hline Overprotective & 24.31 & 7.08 & 24.03 & 7.69 & 0.55 & .582 \\
\hline
\end{tabular}


Education level was of importance for some of the parental attitudes. Mothers with higher education have the highest (ANOVA: $F=3.75, p=.025)$ levels of the overdemanding attitude (in sten values: $M=7.15)$ in comparison to both mothers with secondary education $(M=6.79$, Tukey test: $p=.014)$ and those with vocational education $(M=6.77, p=.050)$. Opposite results were obtained for the autonomy attitude $(F=5.63, p=.004)-$ mothers with higher education exhibit the lowest levels of this attitude $(M=2.75)$, lower than the mothers with secondary education $(M=3.35, p=.003)$ and those with vocational education $(M=6.77, p=.003)$. Interestingly, the levels of the autonomy attitudes were the highest $(F=4.21, p=.016)$ in fathers with vocational education $(M=3.10)$ - higher than among fathers with secondary education $(M=2.63, p=.035)$ and those with higher education $(M=2.23, p=.006)$. The main effects analysis (parent's education $\times$ child's sex) did not reveal the child's gender to be important with regards to the presented parental attitudes depending on parents' education.

\section{PARENTS' SEXISM}

In terms of sexism, fathers exhibited higher levels of hostile sexism (Table 2) than did mothers, independent of whether they were raising a daughter or a son. Similarly to the case of parental attitudes, it was of no importance whether the child had siblings or was an only child, nor was the family's area of residence relevant. The levels of sexism among fathers was also not correlated with their age, whereas among mothers sexism became lower with age $(r=-.23, p=.007)$. Levels of hostile and benevolent sexism were similar among fathers, whereas among mothers levels of benevolent sexism were significantly higher than levels of hostile sexism $(t=4.71, p<.001)$.

Education levels are important for the intensity of sexism only in the case of mothers. Women with higher education exhibit the lowest levels of hostile sexism (ANOVA: $F=4.30, p=.014, M=27.55$ ) in comparison to both mothers with secondary education $(M=29.07$, Tukey test: $p=.041)$ and those with vocational education $(M=30.23, p=.009)$. In the case of benevolent sexism there was a difference $(F=4.30$, $p=.014)$ between mothers with higher education $(M=31.48)$ and mothers with secondary education
$(M=33.75)$. The analysis of main effects (education $\times$ child's sex) did not reveal the child's gender as being important for the levels of sexism dependant on the parent's education.

\section{SEXISM AND PARENTAL ATTITUDES}

Multiple regression analysis was used in order to verify hypothesis 1 . In the analysis, parental attitudes constituted explained variables and sexism, age, and the education of parents were explanatory variables.

In the case of mothers, none of the explanatory variables influenced the acceptance-rejection and demanding attitudes. Results of the regression analysis $\left(R^{2}=.13, F=9.56, p<.001\right)$ indicate that the levels of the autonomy attitude were influenced by: mother's education levels $(\beta=-.14, p=.015)$, hostile sexism $(\beta=-.12, p=.040)$ and benevolent sexism $(\beta=-.24$, $p<.001)$. The inconsequence attitude was influenced $\left(R^{2}=.11, F=7.87, p<.001\right)$ by: hostile sexism $(\beta=-.25, p<.001)$ and benevolent sexism $(\beta=-.13$, $p=.034)$. The overprotective attitude was influenced $\left(R^{2}=.09, F=6.86, p<.001\right)$ only by hostile sexism $(\beta=-.31, p<.001)$.

Sexism, age and education of fathers did not influence the acceptance-rejection, demanding and overprotective attitudes. Results of regression analysis $\left(R^{2}=.09, F=6.67, p<.001\right)$ suggest that the levels of the inconsequence attitude were influenced by hostile sexism $(\beta=.26, p<.001)$. The autonomy attitude was influenced to a small extent $\left(R^{2}=.08, F=5.70\right.$, $p<.001)$ by: hostile sexism $(\beta=.15, p=.016)$, benevolent sexism $(\beta=.13, p=.015)$ and education $(\beta=-.15$, $p=.010)$.

It turns out that the gender of a child moderates the relationship between parents' sexism and parental attitudes (hypothesis 2). In the case of mothers who have a son, there was an increase of the negative influence of benevolent sexism on overprotective attitude $(\beta=-.24, p=.005)$, and overdemanding attitude $(\beta=-.18, p=.044)$. These relations were not present in the case of having a daughter. Apart from this, the higher the levels of education of mothers, the more demanding they were, but only towards their sons $(\beta=.21, p=.017)$.

In the case of fathers, the inconsequence attitude increased under the influence of hostile $(\beta=.32$, $p<.001)$ and benevolent $(\beta=.26, p=.001)$ sexism, if
Gender as a moderator of the relationship between sexism and parental attitudes

\section{Table 2}

Differences between mothers and fathers in terms of intensity of sexism

\begin{tabular}{lcccccc}
\hline \multirow{2}{*}{ Sexism } & \multicolumn{2}{c}{ Mother } & \multicolumn{2}{c}{ Father } & \multicolumn{2}{c}{ Difference } \\
\cline { 2 - 7 } & $M$ & $S D$ & $M$ & $S D$ & $t$ & $p$ \\
\hline Benevolent sexism & 32.46 & 6.69 & 32.19 & 6.66 & 0.57 & .571 \\
Hostile sexism & 28.46 & 5.65 & 32.28 & 7.05 & 7.54 & $<.001$ \\
\hline
\end{tabular}


they had a son. No such relationship occurred if they had a daughter. Also, the hostile sexism of fathers of daughters (not sons) amplified the overprotective attitude $(\beta=.24, p=.005)$. Meanwhile, the autonomy attitude (only in the case of having a daughter) was influenced by: hostile sexism $(\beta=.19, p=.022)$, benevolent sexism $(\beta=.21, p=.011)$ and education levels $(\beta=-.19, p=.018)$.

Małgorzata

Lipowska, Mariusz Lipowski, Paulina Pawlicka

\section{PROFILE OF PARENTAL ATTITUDES}

First, it is important to note that in comparison to normalised results, the attitudes of mothers and fathers were consistent. While there were statistically significant differences in the intensity of the acceptance-rejection and autonomy attitudes, they did not cause a change in sten scores. The obtained data showed that parents reported low levels of autonomy and protection attitudes, high levels of inconsequence attitude and moderate levels of acceptance-rejection and demanding attitudes. When interpreting the results, one ought to remember that a different level of each attitude is thought to be optimal for a child's development (Plopa, 2008).

When analysing the obtained profiles of parental attitudes in accordance with the intention of the test's author, one ought to consider low scores on the scale of protective attitude to be most favourable for the upbringing process. This is a surprising result, because a tendency to protect children from any kind of risk in their childhood is frequently discussed (Ungar, 2009). All participants were parents of five-yearolds who were in obligatory pre-school education. It frequently occurs that children of this age are treated like "pups". Pre-school teachers often state that a lot of children who start pre-school education are very dependent, because parents do too many things for them, both in terms of self-sufficiency (dressing or eating), and initiating contact with peers (Sosnowska, 2013). On the other hand, one could postulate distinguishing between two types of independence: that associated with self-sufficiency and that associated with independent decision making. While most parents try to foster the development of self-sufficiency in children, they often limit their right to make decisions about themselves (Becker, Ginsburg, Domingues, \& Tein, 2010; Kelly \& Dupasquier, 2016). The most common source of these behaviours is concern for their offspring; however, it is also associated with higher levels of anxiety and depressiveness in parents (Erozkan, 2012; Möller et al., 2016). The number of social situations in which the children or youths themselves make decisions increases with age, and this may be associated with intensification of parents' tendencies towards overprotectiveness. It is possible that the studied parents of five-year-olds were not yet exposed to situations in which their children make independent choices. However, it should be expected that among some of them the tendency for overprotectiveness will intensify in the future. Yet the fact that parental attitudes rarely undergo drastic changes unless serious life crises occur, such as family breakdown (Uphold-Carrier \& Utz, 2012) or chronic illness of the child (Jankowska, Włodarczyk, Campbell, \& Shaw, 2015), allows one to remain optimistic that the levels of the overprotective attitude will remain low.

Referring to the scales of the SPR test (Plopa, 2008), low levels of autonomy and high levels of inconsequence attitudes should be regarded as unfavourable for children's development. However, it should not be forgotten that there is a need to adjust the attitude to the developmental stage of the child; a low acceptance of the autonomy of a five-year-old may simply stem from the age of the child. The closeness of parents and children at an early stage guarantees stable development based on trust and a full sense of security (Kelly \& Dupasquier, 2016). Most reviews in the area of educational psychology suggest that an increase in the elasticity of parents' behaviour is appropriate, increasing freedom as the child gets older until the period of adolescence, when striving for autonomy and self-determination reaches its climax (Borchet et al., 2016). Unfortunately the result suggesting a lack of consequence of grown-ups seems to be unequivocally unfavourable. Already setting clear boundaries in early childhood allows the child to learn about the rules governing the world, obviously with different levels of generalisation: from rules that are in place in a given family to general rules associated with social life (Borecka-Biernat, 2003). Inconsequence results in a lack of sense of security: the parent seems unpredictable to the child, as their behaviour depends on their current mood. Therefore it is difficult to develop a consistent way of perceiving social situations, and the child is not sure whether the consequences of their actions will be positive or negative, whether they should expect praise or punishment for a given behaviour; moreover they have to attend to the parent's emotions, because the parent's emotions decide on the intensity of rewards or punishments. Such situations may cause internal insecurity and anxiety in a child (Becker et al., 2010; Cabrera et al., 2011).

The average intensity of acceptance-rejection and demanding attitudes is believed to be typical for most Polish families (Plopa, 2008). The overall profile of parental attitudes exhibited by the studied group of parents of five-year-olds is quite surprising. Results indicating low levels of overprotective attitude and simultaneous high inconsequence are inconsistent. It seems that parents are not convinced of the validity of the way they should treat their children. The 
traditional model of upbringing assumes the dominance of grown-ups (Bakiera, 2006), based on a set of responsibilities that is slowly replaced by a more democratic approach and increasing emancipation of the children (Płeczkan, 2012; Wakulska, 2014). Metaanalyses of changes of social functioning often suggest the existence of a transition period characterised by instability and apparent lack of consistency (Cancian \& Reed, 2009; Majorczyk, 2010).

Both the high consistence of attitudes of both parents and, most of all, the lack of difference of attitudes depending on the sex of the children are striking. Many authors talk about the differential treatment of boys and girls (Endendijk, Groeneveld, Bakermans-Kranenburg, \& Mesman, 2016), but studies are usually concerned with children in primary schools and youths, not preschoolers. While in Polish society, parents usually strongly stress differences between daughters and sons, maybe in the preschool period this applies to the child's appearance - i.e. the way they are dressed, the way their hair is styled, or the type of toys they are given (Pomerleau, Bolduc, Malcuit, \& Cossette, 1990) - rather than the assumed parental attitudes. In the period of late childhood and adolescence the increasingly gender-specific expectations that are in line with gender roles accepted in a given society become apparent. This is why parents' sexism was included in this study as a moderator of attitudes.

\section{SEXISM AS A MODERATOR OF PARENTAL ATTITUDES}

In terms of the intensity of sexism, the results of the current study indicated higher levels of hostile sexism among men, which is in line with Polish findings by Zawisza, Luyt, and Zawadzka (2013) and Pietrzak and Mikołajczak (2015) as well as other authors researching the phenomenon in other countries (see Glick \& Fiske, 2001). The precarious manhood theory (Vandello \& Bosson, 2013) according to which men compensate for their masculine insecurity by adopting more masculine behaviours to recover their masculine status, may serve as a possible explanation for men's higher HS results. However, as distinct from the report by Zawisza et al. (2013), in which the levels of benevolent sexism were higher than hostile sexism in the entire group of participants, in our study both types of sexism are on the same level among men. The parameter which differentiates the two studies is mainly the education level of participants, who were students in the Zawisza et al. study and parents of five-year-olds with varying levels of education in our study. Other authors also talk about the role education plays in sexism (see Glick, Lameiras, \& Castro, 2002; Garaigordobil \& Aliri, 2012; Pietrzak \& Mikołajczak, 2015). It is worth highlighting that in the present study higher levels of education were associated with lower levels of sexism, both benevolent and hostile, but only among women. It is possible to infer that the awareness of sexist behaviour increases among women alongside the level of education. This refers mostly to benevolent sexism, which is often completely ignored, marginalised and treated as a form of elegant or chivalrous social behaviour. Additionally, lower levels of benevolent sexism among younger women may suggest the role of socio-cultural influences on the intensity of sexism. Poland is a country where the "chivalrous" treatment of women has a very long tradition: it is still almost universal to let women through doors first, to free seats for them on public transport and, in some circles, to kiss the back of a woman's hand in greeting. The present results indicate that such behaviours are universally accepted both by Polish women and men, which gains particular importance in the context of parental behaviours being the central factor influencing how children acquire traditional versus more liberal gender roles (Montañés et al., 2012; Hess, Ittel, \& Sisler, 2014).

Analysing the relationship between levels of sexism and parental attitudes, the first striking result is that there is a reverse direction of influence of the level of legitimisation of sexist behaviours on the way children are treated - among mothers sexism lowered the autonomy, inconsequence and overprotectiveness attitudes, while among fathers it increased autonomy and inconsequence in relationships with children. This complex relationship intensifies if the sex of the children is taken into account - among mothers this influence additionally increased, but only with regards to sons, while among fathers there are different specific effects on attitudes towards both daughters and sons.

Moreover, it is immensely interesting that sexism influences exactly the same attitudes in mothers and fathers, yet in the opposite direction. Bearing in mind that with regard to each attitude, different levels are optimal for a child's development, it is interesting that sexism in mothers is associated with lower acceptance of autonomy of sons, while among fathers it is associated with higher acceptance of autonomy of daughters.

When analysing the cumulative influence of mothers' sexism on their relations with their sons, it is possible to say that it increases the consistency of their approach - a deeper belief about the rightness of distinct gender roles and acceptance of the polarisation that exists in society causes mothers to express their demands towards their sons in a clearer way. It may seem desirable at first glance, yet if we analyse this relation in terms of its content, it may turn out that there is a clear polarisation of the gender roles of a child at a very early stage in the child's development. High levels of sexism in mothers and low
Gender as a moderator of the relationship between sexism and parental attitudes 
Małgorzata

Lipowska,

Mariusz Lipowski,

Paulina Pawlicka acquiescence towards sons' autonomy may translate into the very clear communication of traditional ways of treating boys. In this context the decrease of emotionally inconsequent behaviours, which seems favourable, may take on a different meaning - lower autonomy together with lower inconsequence may be exhibited in the form of communications such as "you know well how a boy is supposed to act", and if low overprotectiveness is added to that, it is easy to imagine how often the message "don't cry, be a man, not a girl, real men don't cry" is heard in Poland. At the same time, this may be associated with communicating the ideal of chivalry by mothers to their sons, which involves the adoration of women (benevolent sexism) and requirements of strength, courage and toughness. Taking into account the children's age (five), the gravity of this observation increases. While in adolescence, parents of the same sex are the main models for gender roles in children (Montañés et al., 2012; Hess, Ittel, \& Sisler, 2014), in childhood it is the mother who is the main caregiver to a child, and her opinions serve as the basis for developing patterns of appropriate behaviours. Our results can be treated as an empirical indication of widespread differential treatment of small children depending on gender. In the preschool and early school periods, social acceptance of play and toys stereotypically assigned to the other gender applies almost exclusively to girls. They play with "boyish" toys such as cars or tools increasingly often - even feminised versions of these toys are available, e.g. pink cars for toys (see Weisgram, Fulcher, \& Dinella, 2014). However, letting boys engage in play associated with householding raises objections from adults. Buying dolls, baby carriages, or dishes for boys is considered by caregivers to be unmanly and posing a risk to the child's gender identity. Paradoxically, fathers engage in housework increasingly often (Kosakowska-Berezecka, Korzeniewska, \& Kaczorowska, 2016), and a boy who cooks dinner or feeds a doll may want to "play dad", rather than to pretend to be a girl.

In the case of fathers, the relationship between sexism and parental attitudes is not so clear. In relations with sons, sexism intensifies inconsequent behaviours, which characterise the changeable attitude of a parent towards their child (see Plopa, 2008). This attitude is considered unfavourable, or even one of the possible causes of antisocial behaviours in children (De la Torre-Cruz, García-Linares, \& CasanovaArias, 2014; Chinchilla \& Kosson, 2016). Frequently exhibited high inconsequence by parents is associated with their own lack of belief in the rightness of the child rearing methods they are using (Ziemska, 2009; Raya, Ruiz-Olivares, Pino, \& Herruzo, 2013). It is often stressed that a lack of coherent image of self in the role of a parent translates into a labile attitude towards the child (de Minzi, 2010). Taking into account the relationship between inconsequence and sexism revealed in the current study, one can infer about the role of fathers' uncertainty regarding their own behaviours, congruent or incongruent with the socially accepted gender roles, as well as with current knowledge about the developmental needs of children (children, regardless of their sex, require love, patience, hugging, and a warm relationship - how can this be combined with the requirement to bring up sons as independent, self-confident and dominant?). In many countries, including Poland, the image of a father is undergoing some very intensive changes - from patriarchy to a more egalitarian division of roles (Kosakowska-Berezecka, Kaczorowska, \& Korzeniewska, under review; Vandello, Hettinger, Bosson, \& Siddiqi, 2013; International Men and Gender Equality Survey (IMAGES); United Nations, 2012).

Fathers' sexism is associated with intensity of autonomy and overprotectiveness in their relationships with daughters. When analysing this result, it is crucial to take into account the age of the children - in Poland the expression "father's daughter" is used very often. This commonly refers to a relationship where the father lets his daughter "do anything"; she is "the apple of his eye" and his "little princess". Even these phrases themselves are indicative of stereotypical treatment of girls. Publications in the field of clinical psychology demonstrate that during puberty, girls may be at a very difficult moment in the father-daughter relationship because of the sudden change in the way the young woman is treated (Altman, 2008; Katz $\&$ van der Kloet, 2010). Higher sexism in fathers (especially benevolent sexism) may intensify the belief that while the daughter is young, she ought not to be overly limited by different kinds of prohibitions, and one only needs to take care of her safety.

\section{CONCLUSIONS}

The current results clearly indicate the important role of gender in the relationship between sexism and parental attitudes. According to the initial assumptions, the sex of both parents and children was found to be important. Significantly, sex was important not for the form of parental attitudes themselves - parents exhibited consistent attitudes towards children - but for their relationship with sexism. With regard to the studied parents of preschoolers, the role of sexism in attitudes of mothers towards their sons seems to be the most prominent - it seems that sexism guards the "manliness" of young boys.

Given the limitation of the study regarding the homogeneous age of children - all children were five years old - it is worth attempting to analyse the relationship between sexism and parental attitudes after children enter adolescence - as then the attitude of both adults and children towards gender roles becomes greatly radicalised. 
The preparation of this paper was supported by grant 2015/17/B/HS6/04144 from the National Science Centre, Poland.

\section{References}

Altman, N. (2008). From fathering daughters to doddering father. Psychoanalytic Inquiry, 28, 92-105. doi: 10.1080/07351690701787135

Antill, J. K., Cunningham, J. D., \& Cotton, S. (2003). Gender-role attitudes in middle childhood: in what ways do parents influence their children? Australian Journal of Psychology, 55, 148-153.

Aunola, K., \& Nurmi, J. E. (2005). The role of parenting styles in children's problem behavior. Child Development, 76, 1144-1159.

Aznar, A., \& Tenenbaum, H. R. (2015). Gender and age differences in parent - child emotion talk. British Journal of Developmental Psychology, 33, 148-155.

Bakiera, L. (2006). Rodzina z perspektywy socjologicznej i psychologicznej: ciągłość i zmiana [Sociological and psychological point of view to the family: continuity and change]. Roczniki Socjologii Rodziny, 17, 101-115.

Becker, K. D., Ginsburg, G. S., Domingues, J., \& Tein, J. Y. (2010). Maternal control behavior and locus of control: examining mechanisms in the relation between maternal anxiety disorders and anxiety symptomatology in children. Journal of Abnormal Child Psychology, 38, 533-543.

Biernat, M. (1991). Gender stereotypes and the relationship between masculinity and femininity: A developmental analysis. Journal of Personality and Social Psychology, 61, 351-365.

Bochniarz, A. (2010). Postawy rodzicielskie a funkcjonowanie spoteczne jedynaków [Parental attitudes and the social functioning of only children]. Lublin: Wydawnictwo Uniwersytetu Marii CurieSkłodowskiej.

Borchet, J., Lewandowska-Walter, A., \& Rostowska, T. (2016). Parentification in late adolescence and selected features of the family system. Health Psychology Report, 4, 116-127. doi: 10.5114/ hpr.2016.55921

Borecka-Biernat, D. (2003). Postawa wychowawcza w rodzinie jako wyznacznik unikowej strategii radzenia sobie młodzieży w trudnej sytuacji kontaktu społecznego [Upbringing attitude in families as a determinant of avoidance coping strategies of youth in difficult social interactions]. In I. Janicka \& T. Rostowska (eds.), Psychologia w stużbie rodziny [Psychology as a service to the family] (pp. 166-184). Łódź: Wydawnictwo Uniwersytetu Łódzkiego.

Bosak, J., Sczesny, S., \& Eagly, A. H. (2012). The impact of social roles on trait judgments: A critical re-examination. Personality and Social Psychology Bulletin, 38, 429-440.

Boski, P. (1999). Męskość - kobiecość jako wymiar kultury. Przegląd koncepcji i badań [Masculinity-femininity as a dimension of culture. Review of concepts and research]. In J. Miluska \& P. Boski (eds.), Męskość - kobiecość w perspektywie indywidualnej $i$ kulturowej [Masculinity-femininity in individual and cultural perspectives] (pp. 66-97). Warszawa: Wydawnictwo Instytutu Psychologii PAN.

Brown, S., Fite, P. J, \& Poquiz, J. (2016). Moderating effects of gender on outcomes associated with stressful life events among elementary school-age youth. Child Psychiatry and Human Development, 47, 593-602.

Cabrera, N. J., Fagan, J., Wight, V., \& Schadler, C. (2011). Influence of mother, father, and child risk on parenting and children's cognitive and social behaviors. Child Development, 82, 1985-2005. doi: 10.1111/j.1467-8624.2011.01667.x

Cancian, M., \& Reed, D. (2009). Family structure, childbearing, and parental employment: Implications for the level and trend in poverty. Focus, 26, 21-26.

Chinchilla, M. A., \& Kosson, D. S. (2016). Psychopathic traits moderate relationships between parental warmth and adolescent antisocial and other highrisk behaviors. Criminal Justice and Behavior, 43, 722-738. doi: 10.1177/0093854815617216

Chrzan-Dętkoś, M., Kosakowska-Berezecka, N., \& Pawlicka, P. (2011). Women, men and second shift psychological determinants of work-life balance. Polish Journal of Social Sciences, 6, 123-140.

Croft, A., Schmader, T., \& Block, K. (2015). An underexamined inequality: Cultural and psychological barriers to men's engagement with communal roles. Personality and Social Psychology Review, 19, 343-370. doi: 10.1177/1088868314564789

Cunningham, M. (2001). The influence of parental attitudes and behaviors on children's attitudes toward gender and household labor in early adulthood. Journal of Marriage and Family, 63, 111-122.

De Groof, S. (2008). And my mama said...: The (relative) parental influence on fear of crime among adolescent girls and boys. Youth \& Society, 39, 267-293.

De la Torre-Cruz, M. J., García-Linares, M. C., \& Casanova-Arias, P. F. (2014). Relationship between parenting styles and aggressiveness in adolescences. Electronic Journal of Research in Educational Psychology, 12, 147-170.

de Minzi, M. C. R. (2010). Gender and cultural patterns of mothers' and fathers' attachment and links with children's self-competence, depression and loneliness in middle and late childhood. Early Child Development and Care, 180, 193-209.

Deaux, K., \& Lewis, L. L. (1983). Components of gender stereotypes. Psychological Documents, 13, 25-83.
Gender as a moderator of the relationship between sexism and parental attitudes 
Deaux, K., \& Lewis, L. L. (1984). Structure of gender stereotypes: Interrelationship among components and gender label. Journal of Personality and Social Psychology, 46, 991-1004.

Diekman, A. B., Goodfriend, W., \& Goodwin, S. (2004). Dynamic stereotypes of power: perceived change and stability in gender hierarchies. Sex Roles, 50, 201-215. doi: 10.1023/B:SERS.0000015552.22775.44

Eagly, A. H., \& Wood, W. (2012). Social role theory. In P. van Lange, A. Kruglanski, \& E. T. Higgins (eds.),

Małgorzata

Lipowska, Mariusz Lipowski, Paulina Pawlicka Handbook of Theories in Social Psychology (pp. 458-547). London, UK: Sage.

Eagly, A. H., \& Mladinic, A. (1989). Gender stereotypes and attitudes toward women and men. Personality and Social Psychology Bulletin, 15, 543-558.

Eaton, N. R., Keyes, K. M., Krueger, R. F., Balsis, S., Skodol, A. E., Markon, K. E., Grant, B. F., \& Hasin, D. S. (2012). An invariant dimensional liability model of gender differences in mental disorder prevalence: Evidence from a national sample. Journal of Abnormal Psychology, 121, 282-288. doi: $10.1037 / \mathrm{a} 0024780$

Endendijk, J. J., Groeneveld, M. G., Bakermans-Kranenburg, M. J., \& Mesman, J. (2016). Gender-differentiated parenting revisited: meta-analysis reveals very few differences in parental control of boys and girls. PLoS One, 11, e0159193. doi: 10.1371/journal.pone.0159193

Endendijk, J. J., Groeneveld, M. G., van Berkel, S. R., Hallers-Haalboom, E. T., Mesman, J., \& Bakermans-Kranenburg, M. J. (2013). Gender stereotypes in the family context: mothers, fathers, and siblings. Sex Roles, 68, 577-590. doi: 10.1007/ s11199-013-0265-4

Erozkan, A. (2012). Examination of relationship between anxiety sensitivity and parenting styles in adolescents. Educational Sciences: Theory \& Practice, 12, 52-57.

Garaigordobil, M., \& Aliri, J. (2012). Parental socialization styles, parents' educational level, and sexist attitudes in adolescence. Spanish Journal of Psychology, 15, 592-603. doi: 10.5209/rev_SJOP.2012. v15.n2.38870

Glick, P., \& Rudman, L. (2010). Sexism. In J. F. Dovidio, M. Hewstone, P. Glick, \& V. M. Esses (eds.), The SAGE Handbook of Prejudice, Stereotyping and Discrimination (pp. 328-344). London: SAGE Publications Inc.

Glick, P., \& Fiske, S. T. (1996). The Ambivalent Sexism Inventory: Differentiating Hostile and Benevolent Sexism. Journal of Personality and Social Psychology, 70, 491-512.

Glick, P., Lameiras, M., \& Castro, Y. M. (2002). Education and the catholic religiosity as predictors of hostile and benevolent sexism toward women and men. Sex Roles, 47, 433-441. doi: 10.1023/A:1021696209949
Glick, P., Wilkerson, M., \& Cuffe, M. (2015). Masculine identity, ambivalent sexism, and attitudes toward gender subtypes: Favoring masculine men and feminine women. Social Psychology, 46, 210217. doi: $10.1027 / 1864-9335 / \mathrm{a} 000228$

Hess, M., Ittel, A., \& Sisler, A. (2014). Gender-specific macro- and micro-level processes in the transmission of gender role orientation in adolescence: The role of fathers. European Journal of Developmental Psychology, 11, 211-226.

Jankowska, A. M., Włodarczyk, A., Campbell, C., \& Shaw, S. (2015). Parental attitudes and personality traits, self-efficacy, stress, and coping strategies among mothers of children with cerebral palsy. Health Psychology Report, 3, 246-259. doi: 10.5114/hpr.2015.51903

Karasiewicz, K., \& Kosakowska N. (2008). Kij ma dwa końce, mężczyźni też są dyskryminowani ze względu na płeć [The sword is double-edged, men are also disciminated against]. In A. Chybicka \& B. Pastwa-Wojciechowska (eds.), Kobiecość w obliczu zmian. Studia interdyscyplinarne [Femininity in the face of changes. Interdisciplinary studies] (pp. 149-168). Cracow, Poland: Impuls.

Katz, J., \& van der Kloet, E. (2010). The first man in her life: father emotional responsiveness during adolescence and college women's sexual refusal behaviors. American Journal of Family Therapy, 38, 344-356. doi: 10.1080/01926187.2010.493474

Kaźmierczak, M. (2015). Oblicza empatii w procesie adaptacji do rodzicielstwa [Faces of empathy in the process of adaptation to parenthood]. Warszawa: Wydawnictwo Naukowe Scholar.

Kelly, A. C., \& Dupasquier, J. (2016). Social safeness mediates the relationship between recalled parental warmth and the capacity for self-compassion and receiving compassion. Personality \& Individual Differences, 89, 157-161. doi: 10.1016/j. paid.2015.10.017

Kosakowska, N. (2004). Stereotypy kobiecych i męskich ról społecznych w ocenie dzieci, nastolatków i dorosłych [Social role stereotypes of females and males in the eyes of children, adolescents and adults]. Psychologia Rozwojowa, 9, 65-80.

Kosakowska-Berezecka, N., Korzeniewska, L., \& Kaczorowska, M. (2016). Sharing housework can be healthy - cultural and psychological factors influencing men's involvement in household maintenance. Health Psychology Report, 4, 189-201. doi: 10.5114/hpr.2016.62232

Kosakowska-Berezecka, N. (2012). Kiedy kobiety i mężczyźni tracą w oczach innych? - czyli o karach społecznych za niestereotypowe zachowanie słów kilka [When women and men lose in the eyes of others - On social punishments for counterstereotypical behavior]. In N. KosakowskaBerezecka, A. Chybicka, \& P. Pawlicka (eds.), Podróże między kobiecościa a męskościa [Journeys 
between womanhood and manhood] (pp. 125146). Kraków: Oficyna Wydawnicza Impuls.

Laukkanen, J., Ojansuu, U., Tolvanen, A., Alatupa, S., \& Aunola, K. (2014). Child's difficult temperament and mothers' parenting styles. Journal of Child and Family Studies, 23, 312-323. doi: 10.1007/ s10826-013-9747-9

Liberska, H., \& Matuszewska, M. (2006). Pełnienie ról małżeńskich a proces rozwoju dorosłych [Role of marriage and the process of the development of adults]. Psychologia Rozwojowa, 11, 25-35.

Liberska, H., \& Matuszewska, M. (2014). Modele funkcjonowania rodziny. Style wychowania [Models of family functioning. Parenting styles]. In I. Janicka \& H. Liberska (eds.), Psychologia rodziny [Psychology of family] (pp. 115-140). Warszawa: Wydawnictwo Naukowe PWN.

Majorczyk, M. (2010). Współczesna rodzina jako środowisko wychowawcze (socjalizacyjno-enkulturacyjne) [Contemporary family as the environment of the socialization and of the culture]. Scripta Comeniana Lesnensia, 8, 23-40.

Mandal, E. (2004). Podmiotowe i interpersonalne konsekwencje stereotypów zwiazzanych z płcią [Subjective and interpersonal consequences of gender stereotypes]. Katowice: Wydawnictwo Uniwersytetu Śląskiego.

Marchwicki, P. (2004). Style przywiązania a postawy rodzicielskie. Doniesienie z badań [Attachment styles and parental attitudes. A research report]. Roczniki Psychologiczne, 7, 81-103.

Maschi, T., Morgen, K., Bradley, C., \& Hatcher, S. (2008). Exploring gender differences on internalizing and externalizing behavior among maltreated youth: implications for social work action. Child \& Adolescent Social Work Journal, 25, 531-547.

Mikołajczak, M., \& Pietrzak, J. (2014). Ambivalent sexism - A broader conceptualization. Paper presented at the $37^{\text {th }}$ Annual Scientific Meeting of the International Society for Political Psychology, Rome, Italy.

Mikołajczak, M., \& Pietrzak, J. (2015). A broader conceptualization of sexism: the case of Poland. In S. Safdar \& N. Kosakowska-Berezecka (eds.), Psychology of Gender Through the Lens of Culture: Theories and Applications (pp. 169-192). New York: Springer.

Möller, E. L., Nikolić, M., Majdandžić, M., \& Bögels, S. M. (2016). Associations between maternal and paternal parenting behaviors, anxiety and its precursors in early childhood: A meta-analysis. Clinical Psychology Review, 45, 17-33. doi: 10.1016/j.cpr.2016.03.002

Montañés, P., de Lemus, S., Bohner, G., Megías, J. L., Moya, M., \& Garcia-Retamero, R. (2012). Intergenerational transmission of benevolent sexism from mothers to daughters and its relation to daughters' academic performance and goals. Sex Roles, 66, 468-478. doi: 10.1007/s11199-011-0116-0
Moss-Racusin, C. A., \& Rudman, L. A. (2010). Disruptions in women's self-promotion: The backlash avoidance model. Psychology of Women Quarterly, 34, 186-202. doi: 10.1111/j.1471-6402.2010.01561.x

Mulvey, K. L., \& Killen, M. (2015). Challenging gender stereotypes: resistance and exclusion. Child Development, 86, 681-694.

Paulus, F., Backes, A., Sander, C., Weber, M., \& Gontard, A. (2015). Anxiety disorders and behavioral inhibition in preschool children: a population-based study. Child Psychiatry \& Human Development, 46, 150-157.

Pietrzak, J., \& Mikołajczak, M. (2015). Seksizm w Polsce [Sexism in Poland]. In A. Stefaniak, M. Bilewicz, \& M. Winiewski (eds.), Uprzedzenia w Polsce [Prejudices in Poland] (pp. 207-237). Warszawa: Wydawnictwo Stowarzyszenie Filomatów.

Płeczkan, K. (2012). Społeczne role w strukturze współczesnej rodziny [Social roles in modern family structure]. Pedagogika Rodziny, 2, 136-149.

Plopa, M. (2007). Psychologia rodziny: teoria i badania [Family psychology: theory and research]. Kraków: Oficyna Wydawnicza Impuls.

Plopa, M. (2008). Więzi w matżeństwie i rodzinie. Metody badań [Marital and familial ties. Research methods]. Kraków: Oficyna Wydawnicza Impuls.

Pomerleau, A., Bolduc, D., Malcuit, G., \& Cossette, L. (1990). Pink or blue: Environmental gender stereotypes in the first two years of life. Sex Roles, 22, 359-367.

Raboteg-Saric, Z., \& Sakic, M. (2014). Relations of parenting styles and friendship quality to self-esteem, life satisfaction and happiness in adolescents. Applied Research Quality Life, 9, 749-765.

Raya, A. F., Ruiz-Olivares, R., Pino, M. J., \& Herruzo, J. (2013). A review about parenting style and parenting practices and their consequences in disabled and non disabled children. International Journal of Higher Education, 2, 205-213.

Reby, D., Levréro, F., Gustafsson, E., \& Mathevon, N. (2016). Sex stereotypes influence adults' perception of babies' cries. BMC Psychology, 4, 19. doi: 10.1186/s40359-016-0123-6

Rudman, L., \& Mescher, K. (2013). Penalizing men who request a family leave: Is flexibility stigma a femininity stigma? Journal of Social Issues, 69, 322-340. doi: 10.1111/josi.12017

Rudman, L. A., \& Fairchild, K. (2004). Reactions to counterstereotypic behavior: the role of backlash in cultural stereotype maintenance. Journal of Personality and Social Psychology, 87, 157-176.

Rudman, L. A., Moss-Racusin, C. A., Phelan, J. E., \& Nauts, S. (2012). Status incongruity and backlash effects: Defending the gender hierarchy motivates prejudice against female leaders. Journal of Experimental Social Psychology, 48, 165-179. doi: 10.1016/j.jesp.2011.10.008
Gender as a moderator of the relationship between sexism and parental attitudes 
Runions, K. C. (2014). Does gender moderate the association between children's behaviour and teacher-child relationship in the early years? Australian Journal of Guidance \& Counselling, 24, 197-214.

Sosnowska, J. (2013). Adaptation to the institution of a kindergarten - does it concern only the child? In B. Muchacka \& I. Czaja-Chudyba (eds.), Early education. Practice \& Reflection (pp. 66-77). Kraków: Wydawnictwo Naukowe Uniwersytetu Pedagogicznego.

Małgorzata

Lipowska, Mariusz Lipowski, Paulina Pawlicka

Spera, Ch. (2005). A review of the relationship among parenting practices, parenting styles, and adolescent school achievement. Educational Psychology Review, 17, 125-146.

Szmigielska, B., \& Tomaszek, M. (2009). Stereotypy płci w okresie średniego dzieciństwa [Gender stereotypes in kindergarden children]. Psychologia Rozwojowa, 14, 21-31.

Tani, F., Ponti, L., \& Smorti, M. (2014). Shyness and psychological adjustment during adolescence: the moderating role of parenting style. The Open Psychology Journal, 7, 33-44.

Ungar, M. (2009). Overprotective parenting: Helping parents provide children the right amount of risk and responsibility. American Journal of Family Therapy, 37, 258-271.

Uphold-Carrier, H., \& Utz, R. (2012). Parental divorce among young and adult children: A long-term quantitative analysis of mental health and family solidarity. Journal of Divorce \& Remarriage, 53, 247-266.

Vandello, J. A., \& Bosson, J. K. (2013). Hard won and easily lost: A review and synthesis of theory and research on precarious manhood. Psychology of Men \& Masculinity, 14, 101-113. doi: 10.1037/a0029826

Vandello, J. A., Hettinger, V. H., Bosson, J. K., \& Siddiqi, J. (2013). When equal isn't really equal: the masculine dilemma of seeking work flexibility. Journal of Social Issues, 69, 303-321. doi: 10.1111/ josi.12016

Wakulska, D. (2014). Autorytet a wychowanie - czy możliwe jest wychowanie bez autorytetu? Kwartalnik Naukowy Fides Et Ratio, 3, 23-28.

Weisgram, E. S., Fulcher, M., \& Dinella, L. M. (2014). Pink gives girls permission: Exploring the roles of explicit gender labels and gender-typed colors on preschool children's toy preferences. Journal of Applied Developmental Psychology, 35, 401-409. doi: 10.1016/j.appdev.2014.06.004

Williams, J. E., \& Best, D. L. (1990). Sex and psyche: Gender and self viewed cross-culturally. Newbury Park: Sage.

Witkowska, B. (2013). Percepcja postaw rodzicielskich a poziom samooceny dziewcząt z anoreksją psychiczną. Psychiatria Polska, 47, 397-409.

Wood, W., \& Eagly, A. H. (2002). A cross-cultural analysis of the behavior of women and men: implications for the origins of sex differences. Psychological Bulletin, 128, 699-727. doi: 10.1037//0033-2909.128.5.699

Wood, W., \& Eagly, A. H. (2012). Biosocial construction of sex differences and similarities in behavior. In J. M. Olson \& M. P. Zanna (eds.), Advances in Experimental Social Psychology (pp. 55-123). Burlington: Academic Press.

Young, R., Lennie, S., \& Minnis, H. (2011). Children's perceptions of parental emotional neglect and control and psychopathology. Journal of Child Psychology and Psychiatry, 52, 889-897.

Zawisza, M., Luyt, R., \& Zawadzka, A. M. (2013). Societies in transition: Are they more sexist? A comparison between Polish, South African and British samples. Journal of Gender Studies, 24, 38-55.

Ziemska, M. (2009). Postawy rodzicielskie [Parental attitudes]. Warszawa: Wydawnictwo Wiedza Powszechna. 